\title{
The Stability of Money Demand Function in Sri Lanka: A Bound Cointegration Approach
}

\author{
R.A. Rathnasiri \\ Department of Banking and Finance \\ Faculty of Business Studies and Finance \\ Wayamba University of Sri Lanka \\ SRI LANKA \\ ranasingher76@gmail.com
}

\begin{abstract}
The importance of demand for money has become a prominent research topic in monetary economics due to its role in monetary policy formulation. This paper investigates empirically the determinants of money demand function in Sri Lanka over the period 1977-2019. This study estimates both short run and long run money demand function using monetary aggregates M1 and M2 based on time series data. The explanatory variables used in the study comprised with stability variables such as Inflation rate, exchange rate and Gross Domestic product, Opportunity cost variables such as short run interest rate and long term interest rate and other macroeconomic variables such as government expenditure, interest rate spread and economic crisis. Annual time series data has been taken to estimate determinants of money demand. The estimates of the long run relationship is obtained by using bound cointegration technique and the vector error correction technique was used to estimate of the short run dynamics of the long run equation. Findings of the study confirmed real GDP, interest rate, government expenditure, inflation rate, interest rate spread and economic crisis has significant relationship with the money demand in Sri Lanka. According to the stability test, the empirical results show that the both M1 and M2 money demand functions are stable for the period 1977-2019. Results indicate that both M1 and M2 are suitable for the monetary policy formulation. Thus, Sri Lanka's current practice of monetary targeting framework using broad money as an intermediate target is viable. This study provides the policy challenges that Sri Lankan economy meets to develop favorable macroeconomic environment in order to manage money demand for a sustainable growth.
\end{abstract}

Keyword:- Money Demand, ARDL Model, Stability Tests, Sri Lank. 


\section{INTRODUCTION}

The liquidity preference or demand for money is the most vital and crucial major macroeconomic variable in determining economic and financial sector development in any country (Tan, 1997; Goldfeld, 1994). The money demand function of an economy reflects an overview on which ways and means economic agents fulfill their liquidity requirements. Thus, it is one of the key components in formulating effective monetary policy. Under the monetary Law Act, the central bank of Sri Lanka as the apex institution in the financial system has the sole authority to design and implement appropriate monetary policy with a view to achieving price stability and the financial system stability and thereby promote economic growth and development. Therefore, in the monetary policy formulation the estimation of money demand function cannot be underestimated. Moreover, the stable money demand function and robust determinants of money demand is a pre requisite to achieve the macroeconomic objectives through effective monetary policy (Kontolemis 2002; Abbas and Muhammad 2003; Umbreen et al., 2016; Manamba,2017).

In economic theory specified the importance of estimating money demand in the policy formulation process. For an instance in the famous macroeconomic model of IS-LM identified money demand as the main predictor of the effectiveness of the monetary policy in which income elasticity of money demand and interest elasticity of money demand are predominant in the money demand function. Further, stable money demand function helps policy makers to understand the behavior of monetary transmission mechanism (Nandasiri et al., 2015). This clearly indicates the monetary influences are transmitted to other sectors of the economy such as financial and goods market. Hence, the effectiveness of the monetary policy highly depends on the nature of the determinants of money demand and the stability of the money demand function in the long run.

According to the Friedman (1956) quantity theory of money, expresses money demand as a function of income and the cost of holding money. The development of monetarism has paved attention to the role of money in economic growth. Hence, there are large number of empirical research done on the determinants and stability of money demand function in both developed and developing countries (Simmons, 1992, Hayo, 1999, Sriram, 2000). However, until recently, there were limited researches on money demand estimation in the context of Sri Lankan economy (Weliwita and Ekanayake 1998; Dharmadasa, and Nakanishi 2013; Nandasiri et 
al., 2015). Most of the above studies identified narrow money demand is more stable than the broad money demand in Sri Lanka. But, later few studies confirmed broad money demand is more stable in Sri Lanka over time (Adikari, 2015; Nandasiri et al., 2015; Jegajeevan, 2015). Thus, the available literature provide inconclusive outcome about the stability of money demand function in Sri Lanka. Hence, the purpose of this study is to investigate the main determinants of demand for money in Sri Lanka while testing the stability of the money demand function over the study period of 1977 to 2019.

The money demand refers to the aggregate form represents total demand for money by the public in spendable form. The stability of the money demand function varies with the stage of development of the financial sector (Tan 1997). At the early stages of development, it is typical for an economy to achieve a downward trend in money velocity with the growing degree of monetization in the economy however, when financial sector becomes complex with its development reversal could be seen in the money velocity with respect to the financial innovations making choice between money and non-money which explain other form of financial instruments. Hence, the variation in the velocity with respect to the stage of development of the financial market would cause to undermine the stability of the money demand function. In Sri Lanka, financial sector development is remarkable with the introduction of the liberalization policies after 1977. The technological advancement and the development of communication systems has altered the financial products, financial services, markets and payment and settlements systems in Sri Lanka proving that the financial sector as the most innovative sector in the economy. Thus, financial innovations have dramatically changed the nature of the financial products make available and trade related activities generate instability in the money demand function in Sri Lanka. However, comparison to other Asian countries financial market in Sri Lanka especially money market and forex market are somewhat lagged behind mainly due to shortage of liquidity and low level of financial depth (Dharmadasa et al., 2013). Further the pressure on financial market further exaggerated due to heavy government intervention in the financial market. For an instance, government borrowing from the financial market was 34 per cent to finance the fiscal deficit in the year 2017 in which 26 percent represent borrowing from banking sector (CBSL 2018). The monetization of the economy which represents $\mathrm{M} 1$ and $\mathrm{M} 2$ as a percentage of GDP is stood at $6 \%$ and $46 \%$ respectively (CBSL, 2019). Thus, the purpose of this study is to examine the vital 
determinants of the money demand function and assess the stability of the money demand function over the study period in Sri Lanka. In order to achieve above objectives, this study concerns on following to research questions, firstly, what are the determinants of money demand function in Sri Lanka? Secondly, is the money demand function stable over the time?

The present study differs from the existing literature in this area several ways. In economic literature, dearth of studies is available to examine the determinants of money demand function in Sri Lanka. The current study has been undertaken with the motivation of fill this gap as a first instance in the Sri Lankan context. Secondly, the inclusion of both broad and narrow money balances as a proxy for money demand brought forward new focal area of money demand function. Thirdly, this study uses interest rate spread as a financial development indicator which affect to money demand in Sri Lanka an important issue which has been not investigated by previous scholars. Inclusion of interest rate spread and exchange rate provide an important determinant of money demand in the phase of financial liberalization policies adopted during the study period.

The analytical process of the current paper comprises with following steps. After checking stationary properties of variables, the long run money demand function is estimated based on cointegration approach with error correction model using annual time series data for the narrow money demand and broad money demand separately. The later explains the general to specific approach of money demand and its determinants. It is envisaged that useful policy implications can be derived from this investigations as money demand represent an important channel of monetary policy transmission mechanism. This study comprises with five sections. Section one is the introduction part identified the background information relation to issue with its objectives significance. Section two summarizes the literature review. Section three explains the data sources and technical root of the study including the methodology. Section four deals with the empirical results and final section summarizes the conclusion of the study.

\section{LITERATURE REVIEW}

The importance of money demand function has become popular topic among economists, policy makers in recent years. There has been extensive research on the demand for money, however key focus of those studies are varied in accordance with time span, choice of variable selection and motives of money demand across developed and developing nations (Hoffman et al., 1995; Weliwita and Ekanayaka 1998; 
Dharmadasa and Nikanishi 2013; Melih 2014). This is due to the fact that empirical estimation of money demand function is important for the policy makers to ensure the effectiveness of the monetary policy. Moreover, in the rapid pace of financial sector development, the role and effectiveness of money and monetary development become one of the most important focal areas in the monetary agenda.

The demand for money in the literature can be classified as the traditional view and the modern view. The traditional view as specified in the theoretical literature identified money demand function as a function of real income, interest rate and wealth. Modern approach identified number of other factors such as Inflation, Exchange rate, Budget deficit, population, oil price etc. as the determinants of money demand. These important factors are identified in the broad base literature covering on the developed and developing economies.

\subsection{Theoretical Literature on Money Demand}

In the evolution of economic thought in Fisher (1911) invented the quantity theory of money from the classical school. Quantity theory of money demand identified income as the only determinant of money demand in naïve form expression of MV=PT explanation. Later on Marshall (1923) and Pigou
(1917) presented Cambridge Cash balance approach and concentrate on individual demand for cash balances based on income. Classical theory believes people demand money for transaction purposes as the theory mainly concentrated on neutral role of money in determining output and employment.

In the Keynesian School, Keynes (1936) in his General Theory composite money demand function which is based on three motives namely, transaction demand for money, precautionary demand for money and speculative demand for money. The unique contribution made by the Keynes in his liquidity Preference theory to the money demand function is identification of speculative demand for money which depends on interest rate.

Later on the Portfolio theories of money demand identified the store value function of money where people would like to hold money as a part of portfolio assets. The Monetary school led by Friedman (1956) and Tobin (1958) initiated the portfolio theories of money demand. The development of monetarist's ideas paved the attention to importance of money in determining output and employment. The inventory theories of money demand primarily focused on money as used for the purpose of transaction. Keynes advocated that the transaction demand for money was primarily depends on 
income and it does not depend on interest rate. However, Baumol (1952) analyzed the interest elasticity of transaction demand for money on the basis of inventory theoretical approach. Further, Tobin (1956) invented alternative liquidity theory which explains liquidity preference as behavior towards risk. Both, Baumol (1952) and Tobin (1956) laid foundation to the inventory theory approach.

\subsection{Empirical Literature on Determinants of Money Demand}

Numerous studies attempted to estimate short run and long run relationships between money demand and its determinants in different countries applying different theoretical and methodological approaches. In this section, some of these studies are summarized in terms of their methodologies and findings. A considerable body of literature has examined the money demand function in developing countries (Rabindra and Nirash, 2020; Adikari, A., 2015; Sarwar et al., 2013; Barry and Sumner 2008; Abbas and Mohammad, 2003; Sriram, 2000; Weliwita and Ekanayaka, 1998). However, the studies so far done in the Sri Lankan context are limited in number using time series techniques. A review of the selected empirical studies on the determinants of money demand in Sri Lanka reveals varied results. Most of the previous studies are based on quantitative analysis of the determinants of money demand in Sri Lanka. But, available studies examined factors related to short-run and long-run narrow money demand based on conventional theories, have not been adequately explored other factors which explained money demand with giving due attention on stability of money demand.

The empirical literature which focuses on the conventional theories identified income and interest rate as the most important determinants of money demand in developed as well as developing countries. The most of the studies identified positive association between real income and money demand confirming the theory (Rabindra and Nirash, 2020; Sarwar et al., 2013; Sriram, 2000; Weliwita and Ekanayaka, 1998). Therefore, present study uses real income as the major macroeconomic variable to determine the money demand function in Sri Lanka. Moving to the interest rate, most of the studies treated interest rate as the opportunity cost variable which exerts negative impact on money demand (Rabindra and Nirash, 2020;Umbreen et al., 2016; Bhatta, 2013;Arize and Nam 2012; Tang 2007). But, empirical literature confirmed positive association and negative as well between interest rate and money demand function allowing us to conclude that mix results between the said two variables (Narayan et al ., 2009).Thus, in this study 
interest rate has been taken as the one of the factor which could affect money demand function in Sri Lanka.

Umbreen et al., (2016) examined the set of macroeconomic variables such as interest rate, GDP per capita, exchange rate, fiscal deficit, urban and rural population as the explanatory factors in their model against the money demand function for Pakistan over the period from 1972-2013 using ARDL Bound Testing approach in order to test long run relation between money demand and its factors. And the short run dynamics of the long run model tested using Error correction model. The results show that real interest rate exerts significant and negative effect upon money demand in both long and short run in Pakistan. Moreover, test disclosed that exchange rate and rural population are leaving significant but negative effect on the demand for money. Further, both real GDP and fiscal deficit has insignificant factors in short run as well as long run.

Bhatta (2013) used Bound cointegration approach to examine long run stability of money demand function in Nepal over the period 1975-2009. The test results confirmed the long run cointegration relationship among demand for real money balances, real GDP and interest rate in case of both narrow and broad money supply. The stability test confirmed that both narrow and broad money demand functions were stable in Nepal.

Anwar and Asghar 2012 examines the short run and long run stability of the money demand function in Pakistan using the variables real income, inflation rate and exchange rate by incorporating ARDL approach for the period 1975-2009. Findings of the study revealed that both M1 real money balance and M2 real money balance cointegrated with its determinants but, it has been reported that M2 real money balance is more stable than M1 money demand.

Sulaiman and Hala, (2011) investigate the money demand function in Sudan as a function of real income, inflation and exchange rate against Narrow money demand (M1) using cointegration and error correction model for period 1960-2010.The results confirmed the existence of positive relationship between monetary aggregates and level of income and exchange rate and interest rate negatively affect M1.

Akinsi (2003) investigated money demand function for Turkey using real money balances, real income and interest rate and exchange rate. Model framework developed by cointegration and error correction modeling. Results shows long run demand for real money balance depends on real income, interest rate on government securities and the exchange rate. Moreover, the study found that income elasticity 
and interest elasticity is much weaker in the short run than in the long run, however exchange rate effect is prominent in the short run.

Tang (1997) investigated the money demand function during the liberalization period in Malaysia with a focus on the stability of the money demand functions in different forms of Mo, MI and M2 monetary aggregates against real gross domestic product, interest rates and exchange rate movements using Johansen cointegration techniques from 1973Q1 to 1991Q4. The results confirmed the existence of long run relationship between money demand and its determinants in Malaysia in spite of the financial liberalization and innovations in the financial system. Further in their study income homogeneity assumption of money demand upheld in the long run in respect of Mo and M1 but not in respect of M2 due to the improvements in the financial infrastructure in the system.

In the Sri Lankan Context, studies which focused on the determinants of money demand were limited. The studies related to money demand function in early 1980 's limited to identify the determinants of money demand. These studies examined the specific factors of money demand and failed to address important determinants of money demand for the formation of effective monetary policy
(Jayatissa 1984; Wijewardena 1985). However, in 1990's researchers realized the importance of analyzing the money demand in a full fledge money demand model. Accordingly, Weliwita and Ekanayaka (1998) examined the long run and short run dynamics of money demand function for Sri Lanka during the post liberalization period. This model is enriched with open economy macroeconomic model by incorporating foreign interest rate and real exchange rate as proxy variables for foreign trade and capital movements. The study revealed that M1 is co-integrated with real income, interest rate, short term foreign interest rate and real effective exchange rate whereas M2 was not. This led to the conclusion that monetary authority should consider narrow money definition of money for the liquidity management. Simailar results obtained by Dharmadasa and Nakanishi (2013) and confirmed the above findings. However, Barry and Sumner (2008) questioned about the necessity of introducing foreign interest rate and exchange rate in money demand function.

Dharmarathna (2009) examined the long run demand for money and the short run dynamics of the long run money demand on M1, using quarterly data for 1978 Q1 to 2003 Q4. The findings of the study reveal that M1 is cointegrated with real income and the nominal interest rate. The study, further found that the one 
year term-deposit rate of commercial banks was the best fit for the model used when compared to alternative interest rates such as the 3-month Treasury bill rate, the 12- month Treasury bill rate and the repo rate, implying that the 1-year term deposit rate is the opportunity cost of holding money.

Dharmadasa and Nakanishi (2013) examined the long run money demand function for Sri Lanka using ARDL method for the period 1978 to 2010 . In this study, special attention was given to the effect of financial crisis on money demand function in Sri Lanka. Findings of the study revealed that M1 money demand function is highly cointegrated with the real income; real exchange rate and short term domestic and foreign interest rates confirming the previous findings of the Dharmarathna (2009). Further, study found that financial crisis have significant positive impact on money demand in the short run however; financial crisis did not show significance impact on money demand in the long run.

In conclusion of the theoretical and empirical literature, whole money demand function could be classified as traditional view and modern view of money demand. In the traditional view identified, scale variable (Income) and opportunity cost variables (interest rate and inflation rate) as basic determinants of money demand whereas modern view identified other macroeconomic factors such as exchange rate, population, budget deficit, financial crisis, trade openness as important determinants of money demand.

\section{METHODS}

\subsection{General Model}

In the theoretical literature money demand function, the basic model begins with the basic variables to represent scale variables $(\mathrm{SV})$ which denote the economic activity and opportunity cost of holding money (OC). Thus real money balance (M/P) is a function of economic activity and opportunity cost of holding money. This relationship can be explained as,

$$
M_{t} / P_{t}=f\left(S V_{t}, O C_{t}\right)
$$

But, development of the literature on money demand identified many other factors as the determinants of money demand. These factors are broadly speaking coming under the uncertainty and risk factors which explained under the broad heading of macroeconomic variables. Thus this study identified those factors as other macroeconomic factors $(\mathrm{OM})$ which explain money demand. Thus, the general model can be summarized as follows.

$$
M_{t} / P_{t}=f\left(S V_{t}, O C_{t}, O M_{t}\right)
$$




\subsection{Selection of Variables}

Scale Variable

There is a wide controversy among the researchers on the selection of appropriate variables under each of the above variables explained in the general model in terms of the nature of variable and the sign of the variable. Most studies commonly used income as the scale variable instead of wealth as it difficult to measure due to its complexity and lack of information available on particularly non-monetized economies (Tang, 2007). Most of the studies used real GDP as the proxy variable of income and identified positive association between real GDP and money demand (Rabindra and Nirash, 2020; Nwude et al., 2018;Nam 2012). According to the Keynesian theory when income increases money demand increased under transaction and precautionary motives. This income elasticity of money demand explains two functions of money, namely store value and medium of exchange. Thus there exists positive association between income and money demand. Thus, present study selected real GDP as the scale variable.

\section{Opportunity Cost variable}

Interest rate is the best indicator of the opportunity cost of holding money. As an important monetary policy instrument, assessing the impact of interest rate on money demand is vital (Rabindra and Nirash, 2020). Then the question arise whether to use in more appropriate short run interest rate or long run interest rates. Some argue long run interest rate is more appropriate than short run rates since it more representative of the average rate of return on capital (Dharmarathna, 1999). Moreover, according to the Keynesian theory, long run interest rate is more appropriate since the portfolio investment decisions are negatively linked with long run rate of interest rates. Thus, present study uses, 3 months government Treasury bill rate and long run average commercial banks' lending rates as the opportunity cost variables against the money demand. The current study assumes that interest rate has a negative relationship on money demand function in Sri Lanka.

Other Macroeconomic Variables

The conventional theories of money demand do explain an important aspect of determinants of money demand in closed economic environment. Thus, more efforts have been given by researchers to identify other determinants of money demand (Foresti and Napolitano, 2013). Apart from the above major variables, present study uses set of macroeconomic variables based on the literature in order to identify the long run as well as short run determinants of money demand in Sri Lanka which 
comes under country specific analysis. According to Hassan et al., (2016), money demand function is being affected by number of macroeconomic factors such as inflation, fiscal deficit, public debt, and oil price hikes debt etc. in addition to real income and interest rate, Azim et al., (2010) reported that inflation rate has positively related to money demand while exchange rate affects negatively on money demand. But, Sulaiman and Hala (2011) revealed the negative association between the inflation rate and exchange rate in Sudan. The negative nexus between inflation and money demand conformed people willingness to substitute physical assets to financial assets. This finding is further confirmed by Nandasiri et al., (2016).

In a flexible exchange rate system, Demand for money indeed depends on exchange rate apart from the income and interest rates. According to Arize and Nam (2012); Anwar and Asghar, (2012); Tang (1997) exchange rate is also considered as one of the significant factor which could affect to money demand in an open economic environment. The negative association between exchange rate and money demand confirmed by the theory where depreciation of exchange rate will lead to a decline in domestic currency (Nwude et al., 2018; Hussaini et al., 2018; Umbreen et al., 2016; Dharmadasa and Nakanishi, 2013; Anwar and
Asghar, (2012). According to them rise in exchange rate may result in holding of less demand for local currency and high demand for foreign currency leading to fall in demand for money. This study uses real exchange rate and assumed negative association between real exchange rate and money demand in Sri Lanka.

Fiscal deficit is also considered as an important macroeconomic determinant of money demand in the previous literature. Literature identified mixed results in relation to fiscal deficit and money demand. Vamvoukas, (1998); Umbreen et al., (2016) identified positive association between fiscal deficit and money demand supporting the Keynesian model. But, Deravi et al., (1990) argued that budget deficit has no independent impact on money demand supporting the classical ideas (Barro, 1981). According to the Classical economics demand side factors have no independent impact on real variables. This study uses government expenditure to GDP ratio as a proxy variable for the fiscal deficit and assumed positive association between government expenditure and money demand in Sri Lanka.

The economic and financial crisis create unstable economic environment in most of the countries during the last three decades. Thus, countries had to undergo tight economic controls in order to face the economic and 
financial crisis. These tight economic situations directly affect to quantity of money holdings for different economic requirements. Thus, it is important to investigate the impact of economic crisis on money demand in Sri Lanka. In a study, Dharmadasa and Nakanishi (2013) found financial crisis have a positive significant impact on narrow money balance in the short run but not in the long run. As a result the model framework of the study is enriching by a dummy variable to represent economic crisis. Further, this study uses interest rate spread (interest margin) as a monetization indicator which comes under the macroeconomic environment.

This is an important indicator of efficiency level of the banking system. According to the theory, interest rate spread, which represents the cost of financial intermediation in a competitive environment, should fall as the level of financial intermediation increases. High interest margin is affecting both borrowers and savers, distorting both borrowing and saving decisions. Abbas and Mohammad, (2003) found demand for money negatively related to a rise in the interest rate spread based on the eight developing countries. This factor has not been investigated in the previous literature on the Sri Lankan context.
Monetary Aggregates

The dependent variable, the demand for real money balances measured based on Narrow money (M1) and board money (M2) in real terms. Literature identified both M1 and M2 and a good predictor to measure the money demand and results are varied from country to country based on the country specific factors justifying the importance of country specific analysis in determining the stability of money demand function (Bhatta, 2013).The empirical studies which focused on the money demand in the Sri Lankan context identified M1 as the good predictor of money demand (Dharmadasa and Nakanishi 2013; Dharmarathna, 1999; Weliwita and Ekanayaka,1998). But few studies later confirmed that money demand for M2 is more stable than M1 (Adikari 2015; Nandasiri et al., 2015).

\subsection{Empirical Model for Money Demand Function}

Following the general model for money demand the functional relationship for long term money demand function can be expressed as follows.

$\ln \left(\mathrm{M}_{\mathrm{it}} / \mathrm{P}_{\mathrm{t}}\right)=\beta 0+\beta 1 \ln \mathrm{RGDP}+$ $\beta 2 \ln$ INTR $+\beta 3 \operatorname{lnRER}+\beta 4$ $\operatorname{lnINFR}+\beta 5$ lnGEGDP $+\beta 6$ $\operatorname{lnINSP}+\beta 7 \ln$ TBILL+ $\beta 8 \mathrm{EC}(\mathrm{d})$ $+u \mathrm{t}$ 
Where ln; natural logarithm, $\mathrm{M}_{\mathrm{i}=}$ narrow/broad money supply, $\mathrm{P}$; domestic price level proxied by Implicit price index, RGDP; real income as a measure of scale variable proxied by real GDP, $\beta 0=$ intercept term, $\mathrm{INTR}=$ interest rate as a measure of opportunity cost of money proxied by commercial bank weighted average lending rate, TBill: short run interest rate proxied by 91 treasury bill rate; INFR= inflation rate proxied by annual average percentage change in GDP Deflator; RER ; real exchange rate proxied by nominal exchange rate adjusted for price differentials between two countries USA and Sri Lanka, GEGDP; government expenditure as a percentage of GDP, INSP; interest rate spread proxied by commercial banks average 12 months deposits rate and average lending rates; $\mathrm{EC}(\mathrm{d})$; economic crisis proxied by a dummy variable $(0,1)$ and $\mathrm{U}_{\mathrm{t}}$; white error term; $\beta_{1}, \beta_{2}, \beta_{3}, \beta_{4}, \beta_{5}$, $\beta_{6}, \beta_{7} ; \beta_{8}$ coefficients of the explanatory variables.

\subsection{Data Sources and Analytical Procedure}

This study employed time series data from 1977-2019. The coverage of the study with time series data spanning from 19772019 includes 43 annual data points ensuring the greater opportunity to extract the low frequency information and also use of such long period data points allows us to examine more systematically the question of the stability of the money demand d function over time, a crucial issue in the literature and for the policy makers (Barry and Sumner 2008).

The relevant data was collected from the annual report of the Central bank of Sri Lanka and USA Inflation rate is calculated using the current Consumer Price Index published monthly by the Bureau of Labor Statistics (BLS). First the study checked the stationary of data by using ADF test and PP test because if there are non-stationary data provides spurious regression. Unit root test is used to check whether the variables are in different order of integration to fit in ARDL method. To investigate the long run determinants of money demand, a bound cointegration test under Pesaran et al., (2001) procedure were used. If the value of F-statistic is more than the upper bound I (1) of critical value then study can be concluded that co-integration exists and long-run association is present. When all the variables are co-integrated the study can develop Vector Error Correction Model (VECM) to identify the short run dynamics of the long run model.System model identified the error correction term a value which corrects the disequilibrium of the system. The error correction term should have a negative sign and should be significant. 
Table 1 Selection of Variable \& Definition

\begin{tabular}{|c|c|c|c|}
\hline $\begin{array}{c}\text { Name of the } \\
\text { variable }\end{array}$ & Abbreviation & Data Source & Definition \\
\hline Real GDP & RGDP & $\begin{array}{l}\text { Central Bank } \\
\text { Annual report }\end{array}$ & $\begin{array}{l}\text { annual average real GDP } \\
(1996=100)\end{array}$ \\
\hline $\begin{array}{l}\text { Long term } \\
\text { Interest rate }\end{array}$ & INTR & $\begin{array}{l}\text { Central Bank } \\
\text { Annual report }\end{array}$ & $\begin{array}{l}\text { Commercial Banks } \\
\text { weighted average } \\
\text { lending rate. }\end{array}$ \\
\hline $\begin{array}{l}\text { Short term } \\
\text { interest rate }\end{array}$ & TBILLS & $\begin{array}{l}\text { Central Bank } \\
\text { Annual report }\end{array}$ & $\begin{array}{l}91 \text { days Treasury Bill } \\
\text { rates. }\end{array}$ \\
\hline Inflation Rate & INFR & $\begin{array}{l}\text { Central Bank } \\
\text { Annual report }\end{array}$ & $\begin{array}{l}\text { Annual average change } \\
\text { in Implicit Price Index } \\
(1996=100)\end{array}$ \\
\hline $\begin{array}{l}\text { Government } \\
\text { Expenditure }\end{array}$ & GEGDP & $\begin{array}{l}\text { Central Bank } \\
\text { Annual report }\end{array}$ & $\begin{array}{l}\text { Total government } \\
\text { expenditure as a } \% \text { of } \\
\text { GDP }\end{array}$ \\
\hline $\begin{array}{l}\text { Real Exchange } \\
\text { Rate }\end{array}$ & $R E R$ & $\begin{array}{l}\text { Central Bank } \\
\text { of Sri Lanka } \\
\text { Annual report, } \\
\text { Bureau of } \\
\text { Labor } \\
\text { Statistics } \\
\text { (BLS) USA }\end{array}$ & $\begin{array}{l}\text { Nominal exchange rate } \\
\text { adjusted for price } \\
\text { differentials between US } \\
\& \text { SL }\end{array}$ \\
\hline $\begin{array}{l}\text { Interest rate } \\
\text { Spread }\end{array}$ & INSP & $\begin{array}{l}\text { Central Bank } \\
\text { Annual report }\end{array}$ & $\begin{array}{l}\text { Rate of difference } \\
\text { between commercial } \\
\text { bank average savings } \\
\text { deposits and average } \\
\text { lending rates }\end{array}$ \\
\hline $\begin{array}{l}\text { Economic } \\
\text { Crisis }\end{array}$ & $\mathrm{EC}$ & $\begin{array}{l}\text { Central Bank } \\
\text { Annual } \\
\text { reports }\end{array}$ & $\begin{array}{l}\text { Dummy variable : } \mathrm{EC}=1 \\
\text { indicate presence of } \\
\text { economic crisis and } \\
\mathrm{EC}=0 \text { indicates absence } \\
\text { of economic crisis }\end{array}$ \\
\hline $\begin{array}{l}\text { Real Narrow } \\
\text { Money } \\
\text { Balances }\end{array}$ & $\mathrm{M} 1 / \mathrm{P}$ & $\begin{array}{l}\text { Central Bank } \\
\text { Annual } \\
\text { reports }\end{array}$ & $\begin{array}{l}\text { Narrow money supply } \\
\text { (CC+DD) deflated by } \\
\text { implicit price index }\end{array}$ \\
\hline $\begin{array}{l}\text { Real Broad } \\
\text { Money balance }\end{array}$ & $\mathrm{M} 2 / \mathrm{P}$ & $\begin{array}{l}\text { Central Bank } \\
\text { Annual } \\
\text { reports }\end{array}$ & $\begin{array}{l}\text { Broad money supply } \\
\text { deflated by implicit price } \\
\text { index }\end{array}$ \\
\hline
\end{tabular}


If the error correction term or speed of adjustment is negative sign and significant it confirms the existence of long term relationship between the variables in the money demand model. The study performs parameter instability test using the CUSUM test. This test is based on the cumulative sum of the recursive residuals. The CUSUM test plots the cumulative sum together with the $5 \%$ critical lines. The parameter instability is found if the cumulative sum goes outside the area between the two critical lines. Finally study used diagnostic testing to verify the goodness of the model. This test performs to check whether the variance of the residuals is homoscedastic or heteroscedasticity, the White Heteroscedasticity test is applied to the regression model. By using the Breusch-Godfrey Serial
Correlation LM Test, we check the existence of autocorrelation.

\section{RESULTS AND DISCUS SION}

\subsection{Unit Root Test}

The results of the ADF tests and PP tests are given in Table 2 and Appendix 1 at levels and first difference. According to the test results, the null hypothesis of a unit root at levels in most of the variables can be rejected at 5 percent level. In other words, results clearly show that most of the variables such as LTBILLS, LINTR, INFR, LGEGDP and LRER are stationary at levels except LM1, LM2, LRGDP, and INSP. Thus, the variables LTBILLS,LINTR, INFR, LGEGDP and LRER are in order of integration $\mathrm{I}(0)$ and LM1, LM2,LRGDP,INTSP are in order of integration $\mathrm{I}(1)$.

Table2 Unit Root Test Results

\begin{tabular}{|l|l|l|l|c|}
\hline \multirow{2}{*}{ Variable } & \multicolumn{1}{|c|}{ Model } & \multicolumn{1}{|c|}{$\begin{array}{c}\text { Level } \\
(\mathbf{t}-\mathbf{s t a t})\end{array}$} & $\begin{array}{c}\text { First } \\
\text { Difference } \\
(\mathbf{t} \text {-stat })\end{array}$ & Decision \\
\hline \multirow{2}{*}{ LM1 } & Intercept & -1.2413 & $-7.5795^{* * *}$ & \multirow{2}{*}{$\mathrm{I}(1)$} \\
\cline { 2 - 4 } & Intercept and Trend & -1.3412 & $-7.5726^{* * *}$ & \\
\hline \multirow{2}{*}{ LM2 } & Intercept & -1.3084 & $-2.7382^{*}$ & \multirow{2}{*}{$\mathrm{I}(1)$} \\
\cline { 2 - 4 } & Intercept and Trend & -1.41600 & $-3.9499^{* * *}$ & \\
\hline \multirow{2}{*}{ LRGDP } & Intercept & -0.0861 & $-5.5252^{* * * *}$ & \multirow{2}{*}{$\mathrm{I}(1)$} \\
\cline { 2 - 4 } & Intercept and Trend & -1.4165 & $-5.4652^{* * * *}$ & \\
\hline \multirow{2}{*}{ LTBILLS } & Intercept & -2.4795 & $-6.5766^{* * *}$ & \multirow{2}{*}{$\mathrm{I}(0)$} \\
\cline { 2 - 4 } & Intercept and Trend & $-3.7106^{* * *}$ & $-6.6196^{* * * *}$ & \\
\hline \multirow{2}{*}{ LINTR } & Intercept & -1.7897 & $-9.2439^{* * * *}$ & \multirow{2}{*}{$\mathrm{I}(0)$} \\
\cline { 2 - 4 } & Intercept and Trend & $-3.6036^{* * *}$ & $-9.3379^{* * * *}$ & \\
\hline
\end{tabular}


Rathnasiri R.A., Wayamba Journal of Management 12 (1)

\begin{tabular}{|c|c|c|c|c|}
\hline \multirow{2}{*}{ LINSP } & Intercept & -1.788263 & $-5.359684 * * *$ & \multirow{2}{*}{$\mathrm{I}(1)$} \\
\hline & Intercept and Trend & -2.178712 & $-5.651380 * * *$ & \\
\hline \multirow{2}{*}{ INFR } & Intercept & $\begin{array}{l}- \\
4.330332 * * *\end{array}$ & $-6.277614 * * *$ & \multirow{2}{*}{$\mathrm{I}(0)$} \\
\hline & Intercept and Trend & $\begin{array}{l}- \\
5.021057 * * *\end{array}$ & $-6.186215 * * *$ & \\
\hline \multirow{2}{*}{ LER } & Intercept & $-3.314886^{* *}$ & $-13.41199 * * *$ & \multirow{2}{*}{$\mathrm{I}(0)$} \\
\hline & Intercept and Trend & $-4.850364 * *$ & $-13.85359 * * *$ & \\
\hline \multirow[b]{2}{*}{ LGEGDP } & Intercept & -2.720341 & $-11.05752 * * *$ & \multirow[b]{2}{*}{$\mathrm{I}(0)$} \\
\hline & Intercept and Trend & $\begin{array}{l}- \\
7.145042 * * *\end{array}$ & $-11.47614 * * *$ & \\
\hline \multirow{2}{*}{ FCR } & Intercept & -2.8688 & $-4.8446^{* *}$ & \multirow{2}{*}{$\mathrm{I}(1)$} \\
\hline & Intercept and Trend & -2.8355 & $-4.7326 * *$ & \\
\hline
\end{tabular}

Note: $* * * * * *$ denotes significance at $10 \%, 5 \%$, and $1 \%$ level respectively

That means there exists a mix order of integration with $\mathrm{I}(1)$ and $\mathrm{I}(0)$ variables in the money demand model. Thus, under these circumstances the most suitable method for estimation of long run dynamics is the Autoregressive Distributed Lag Model (ARDL) proposed by Peseran et al., (2001).

\subsection{Long Run Model}

Given the results of stationary test, since all the variables are stationary the model is suitable
For long run analysis. Further, Inverse polynomial function of AR form depicts that the variables are stationary since all variables are lying within the circle (see Figure 1). Under these circumstances, regardless of the order of integration a bound testing can be applied to find out the long run model. As a first step of estimating long run model study examined the maximum lag length as reported in Table 3 based on lag length selection different criteria and established 3 lag lengths for LM1 and LM2. 


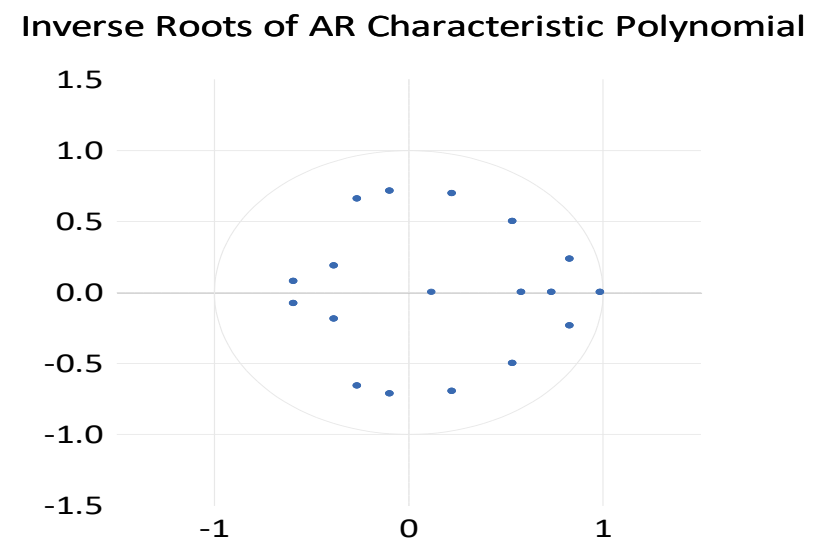

Figure 1: Inverse Roots of AR Characteristic Polynomial

Table 3 : VAR Lag Order Selection Criteria

\begin{tabular}{|c|c|c|c|c|c|c|c|c|c|c|c|c|}
\hline \multirow{2}{*}{$\begin{array}{c}\text { Variable } \\
\text { Lag } \\
\end{array}$} & \multicolumn{6}{|c|}{ M1 } & \multicolumn{6}{|c|}{ M2 } \\
\hline & $\log \mathrm{L}$ & LR & FPE & AIC & $\mathrm{SC}$ & HQ & $\log \mathrm{L}$ & LR & FPE & AIC & $\mathrm{SC}$ & HQ \\
\hline 0 & 116.9 & NA & 3.6 & -5.3 & -5.0 & -5.2 & -6.9 & NA & 1.7 & 0.7 & 1.1 & 0.9 \\
\hline 1 & 384.3 & $401.1 *$ & 3.6 & -14.7 & $10.9 *$ & -13.3 & 290.9 & $446.8 *$ & 3.8 & -10.1 & $-6.2 *$ & -8.6 \\
\hline 2 & 477.2 & 97.5 & 3.8 & -15.3 & -8.1 & -12.7 & 389.7 & 102.9 & 3.1 & -10.9 & -3.6 & -8.2 \\
\hline 3 & 643.3 & 99.6 & $5.2 *$ & $-19.5 *$ & -8.9 & $15.7 *$ & 554.2 & 99.1 & $4.4^{*}$ & $15.1 *$ & -4.4 & $11.2 *$ \\
\hline $\begin{array}{l}\text { indicate } \\
\text { st at } 5 \% \\
\text { formati } \\
\text { ource: A }\end{array}$ & $\begin{array}{l}\text { os lag } \\
\text { level } \\
\text { on crit } \\
\text { uthors }\end{array}$ & $\begin{array}{l}\text { order sel } \\
\text {;FPE: F } \\
\text { erion } \\
\text { Calcula }\end{array}$ & $\begin{array}{l}\text { ected } \\
\text { inal } p \\
\text { inans }\end{array}$ & $\begin{array}{l}\text { oy the c } \\
\text { ediction } \\
\text { ased on }\end{array}$ & $\begin{array}{l}\text { riterior } \\
\text { error; } \\
\text { Surve }\end{array}$ & $\begin{array}{l}\text { AIC: } \\
\text { AIC: } \\
\text { y Data }\end{array}$ & seque & $\begin{array}{l}\text { al modi } \\
\text { nformat }\end{array}$ & & $\begin{array}{l}\text { R test } \\
\text { terion; }\end{array}$ & $\begin{array}{l}\text { statisti } \\
\text { SC: S }\end{array}$ & $\begin{array}{l}\text { ceach } \\
\text { chwarz }\end{array}$ \\
\hline
\end{tabular}

\section{ARDL Bound Test Estimates}

This study uses the bound testing approach developed by Pesaran et al., (2001) to estimate the long run relationship among the variables selected under the two models of narrow money balance and broad money balance. In particular, the analysis of the study investigates whether the signs of the estimated coefficients are in line with their predicted values and whether these estimates are statically significant. Table 4 summarizes the estimated results of $F$ tests for the level of significance. The results reveled that $\mathrm{F}$ statistics is greater than the upper bound critical values for both LM1 and LM2. The calculated critical values clearly exceed the table values at $10 \%, 5 \%$ and $1 \%$ level of significance. Thus, $\mathrm{F}$ statistics clearly reject the null hypothesis 
of no cointegration. It reflects that there exists cointegration or the long run relationship among the variables selected in the two models. Once, the models are confirmed the long term relationship between money demand and its determinants, next step in the ARDL approach is to determine the short run and long run coefficients in the money demand model for Sri Lanka.

Table 4 : ARDL Bound Test Estimates

\begin{tabular}{|c|l|l|l|l|}
\hline $\begin{array}{c}\text { Dependent } \\
\text { variable }\end{array}$ & LOS & \multicolumn{2}{|l|}{ Bound Critical Values } & Test Statistics \\
\hline \multirow{3}{*}{ LM1 } & $1 \%$ & 2.73 & 3.90 & F-stat: 5.805 \\
\cline { 2 - 5 } & $5 \%$ & 2.17 & 3.21 & K:7 \\
\cline { 2 - 5 } & $10 \%$ & 1.92 & 2.89 & \\
\hline & & & & \\
\hline \multirow{3}{*}{ LM2 } & $1 \%$ & 2.50 & 3.68 & Lag: $2,3,1,2,3,3,3,2,2,1$ \\
\cline { 2 - 5 } & $5 \%$ & 2.04 & 2.08 & F-Stat: 13.172 \\
\cline { 2 - 5 } & $10 \%$ & 1.80 & 2.80 & K:9 \\
\hline
\end{tabular}

Source: Author Estimations

The results of the long run cointegration coefficients are reported in the Table 5 . According to long run model 1, it can be concluded that LRGDP, INFR, LEXR, LINSP and LGEGDP have statistically significant but LTBill and LRER have no significant relationship with LM1. Among the significant variables, LRGDP has positive impact on money demand whereas LINTR, INFR and EC have negative impact on money demand. Moreover, LINSP and LGEGDP have weak positive impact on narrow money balances in the long run.

Referring to model 2, reported that LRGDP, LGEGDP has significant positive impact on money demand and LINTR, LTBILL and INFR have negative significant impact on broad money balances in the long run. But, LINSP and LRER have no significant relationship with long term real money balances. These 
results provide strong support for the theoretical predictions regarding the impact of real income, interest rate and inflation rate on money demand function.

Table 5: Long run Money Demand Model for Sri Lanka

\begin{tabular}{|c|c|c|c|c|c|}
\hline $\begin{array}{c}\text { Dependent } \\
\text { Variable }\end{array}$ & $\begin{array}{c}\text { Explanatory } \\
\text { Variable }\end{array}$ & Coefficient & St. error & t-Stat & Prob. \\
\hline \multirow[t]{9}{*}{ Model 1- LM1 } & LRGDP & 1.222 & 0.256 & 4.766 & 0.000 \\
\hline & $\begin{array}{l}\text { LTBILL } \\
\end{array}$ & 0.516 & 0.306 & 1.688 & 0.106 \\
\hline & LINTR & -0.582 & 0.338 & -1.722 & 0.013 \\
\hline & LINSP & 1.689 & 0.895 & 1.887 & 0.072 \\
\hline & $\begin{array}{l}\text { INFR } \\
\end{array}$ & -0.099 & 0.048 & -2.031 & 0.055 \\
\hline & LRER & 0.057 & 0.296 & 0.193 & 0.848 \\
\hline & LGEGDP & 0.906 & 0.443 & 2.045 & 0.056 \\
\hline & FCR & -0.416 & 0.167 & 2.475 & 0.021 \\
\hline & $\bar{C}$ & -20.404 & 15.618 & -1.306 & 0.205 \\
\hline \multirow[t]{9}{*}{ Model 2- LM2 } & LRGDP & 1.663 & 0.696 & 2.389 & 0.026 \\
\hline & LTBILL & -0.383 & 0.152 & -2.513 & 0.027 \\
\hline & LINSP & 0.253 & 0.312 & 0.811 & 0.433 \\
\hline & INFR & -0.063 & 0.027 & -2.303 & 0.040 \\
\hline & LINTR & -0.576 & 0.083 & -6.856 & 0.000 \\
\hline & LRER & -0.085 & 0.126 & -0.669 & 0.516 \\
\hline & LGEGDP & 0.499 & 0.152 & 3.284 & 0.006 \\
\hline & FCR & -0.117 & 0.064 & -1.806 & 0.096 \\
\hline & $\mathrm{C}$ & -39.246 & 13.909 & -2.821 & 0.154 \\
\hline
\end{tabular}

Source: Author Estimation 


\subsection{Short Run Dynamics of the Models}

Given that the above mentioned variables are cointegrated, the next step is to estimate the Vector Error Correction Estimates (VECM) to find out the short run dynamics of the long run model. A summary of the VECM representation of the ARDL selected models are presented in Table 6 below. Each error correction equation includes the error correction coefficient, error correction term, current and first lag values of variables of the first difference of each term lagged once $(t-1)$ variable were reported. All coefficients in the ECM are predicted values with lags are true anti forecasts. The error correction term reflects how quickly the deviation of each variable from the long run equilibrium is corrected gradually towards the equilibrium level through a series of partial short run adjustments. In other words the error correction term expresses the speed of adjustment to restore equilibrium in the dynamic model. Further, in order to confirm the long run relationship, the error correction term should be negative and statistically significant. ECM results shows that most of explanatory variables become significant in the short run broad money demand function except the 91 Treasury bill rates. The short run results of the model 1 and 2 are presented in Table 6 . According to the results positive and significant short run relationship between narrow money balances (M1), real GDP and interest rate spread has been observed. Further negative and significant relationship between M1, long run interest rate, real exchange rate and government expenditure as a percentage of GDP has been observed. Turning to model 2 indicates that positive and significant relationship between M2, real GDP, government expenditure, interest rate spread and financial crisis has been observed. Further, negative relationship between M2, first lag of M2, interest rate, inflation rate and real exchange rate has been observed. Whereas, both inflation rate and 91 days TBILL rates are found as insignificant factors in the short run narrow money demand function and broad money balance respectively. Thus, generally, real GDP, interest rate, real exchange rates, interest rate spread and government expenditure can be identified as the major determinants of short run money demand function in Sri Lanka. Estimated error coefficient (EC) is statistically significant at $1 \%$ and negative sign in both cases indicating long run relationship between money demand and its determinants. In the first model, the EC term is greater than 1 , and it is 1.0294 implies that deviations from the long term growth rate is corrected by the following year by $1.03 \%$. But, in the second model, there is a weaker speed of adjustment to correct the equilibrium in the dynamic model (i.e $0.18 \%$ ). 
After discussing the short run coefficient, stability of the money demand function is tested during the period 1977-2019.

\subsection{Stability Tests}

Parameter constancy is a critical issue for money demand function. In order to test the stability of the money demand function, study employed the methodology of cumulative sum (CUSUM) and the cumulative sum of squares (CUSUMSQ) tests proposed by Brown et al., (1975). As shown in the Figure 2 and 3, neither the CUSUM nor CUSUMSQ plots cross the 5\% critical lines, thus study can conclude that the estimated parameters for the short run and long run real M1 and M2 demand functions in Sri Lanka are stable.

Table 6 : Error Correction Model Regression Results

\begin{tabular}{|c|c|c|c|c|}
\hline \multirow[t]{2}{*}{ Variable } & \multicolumn{2}{|c|}{$\begin{array}{c}\text { Model 1 } \\
\text { Selected model: } \\
\mathbf{1 , 1 , 1 , 2 , 2 , 3 , 0 , 2 , 0}\end{array}$} & \multicolumn{2}{|c|}{$\begin{array}{c}\text { Model 2 } \\
\text { Selected model: }\end{array}$} \\
\hline & Coefficient & t-ratio & Coefficient & t-ratio \\
\hline$\overline{\mathrm{D}(\mathrm{LM} 2(-1))}$ & & & $\begin{array}{l}-0.4432 \\
\end{array}$ & $-5.0268^{* * * *}$ \\
\hline D(LRGDP) & 3.8406 & $3.9650 * * *$ & 0.3011 & $3.9208^{* * *}$ \\
\hline $\mathrm{D}$ (INFR) & -0.0259 & -1.5893 & -0.0062 & $-8.4661 * * *$ \\
\hline$\overline{\mathrm{D} \text { (LGEGDP) }}$ & 0.8098 & 1.0200 & -0.2535 & $-6.5003 * * *$ \\
\hline$\overline{\mathrm{D}(\text { LGEGDP }(-1))}$ & -2.5622 & $-4.2363 * * *$ & 0.3339 & $9.3511 * * *$ \\
\hline$\overline{D(\text { LINSP) }}$ & 1.2994 & $2.2380 * *$ & $\begin{array}{l}-0.0040 \\
\end{array}$ & -0.1526 \\
\hline $\mathrm{D}(\operatorname{LINSP}(-1))$ & 1.4481 & $3.1138^{* * *}$ & 0.1086 & $4.4846 * *$ \\
\hline$\overline{D \text { (LRER) }}$ & -0.0322 & -0.4431 & -0.0194 & $-4.7999 * *$ \\
\hline$\overline{\mathrm{D}(\operatorname{LRER}(-1))}$ & -0.2823 & $-2.7987 * *$ & -0.0191 & $-3.6035^{* *}$ \\
\hline D(LINTR) & -2.4509 & $-2.8252 * *$ & $\begin{array}{l}-0.0769 \\
\end{array}$ & $-1.8510^{*}$ \\
\hline D(LINTR(-1)) & $\begin{array}{l}-1.9711 \\
\end{array}$ & $-3.2086^{* *}$ & $\begin{array}{l}-0.3111 \\
\end{array}$ & $-7.6372 * * *$ \\
\hline $\mathrm{D}(\mathrm{FCR})$ & & & 0.0221 & $3.8577 * *$ \\
\hline
\end{tabular}


Rathnasiri R.A., Wayamba Journal of Management 12 (1)

\begin{tabular}{|l|l|l|l|l|}
\hline $\mathrm{D}(\mathrm{FCR}(-1))$ & & & 0.040 & $6.2399^{* * *}$ \\
\hline $\mathrm{D}(\mathrm{LTBILL})$ & & & -0.0131 & -1.1130 \\
\hline ECM term(-1) & -1.0294 & $-9.1066^{* * *}$ & -0.1833 & - \\
& & & & $\begin{array}{l}15.1828^{* *} \\
*\end{array}$ \\
\hline
\end{tabular}

Note: $* * * * * *$ denotes significance at $10 \%, 5 \%$, and $1 \%$ level respectively Source: Author Estimation
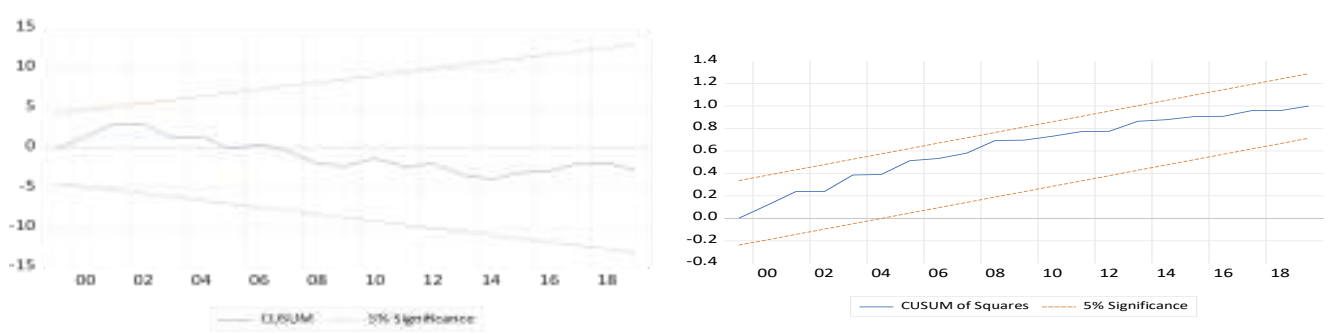

Figure 2: Stability Tests for M1

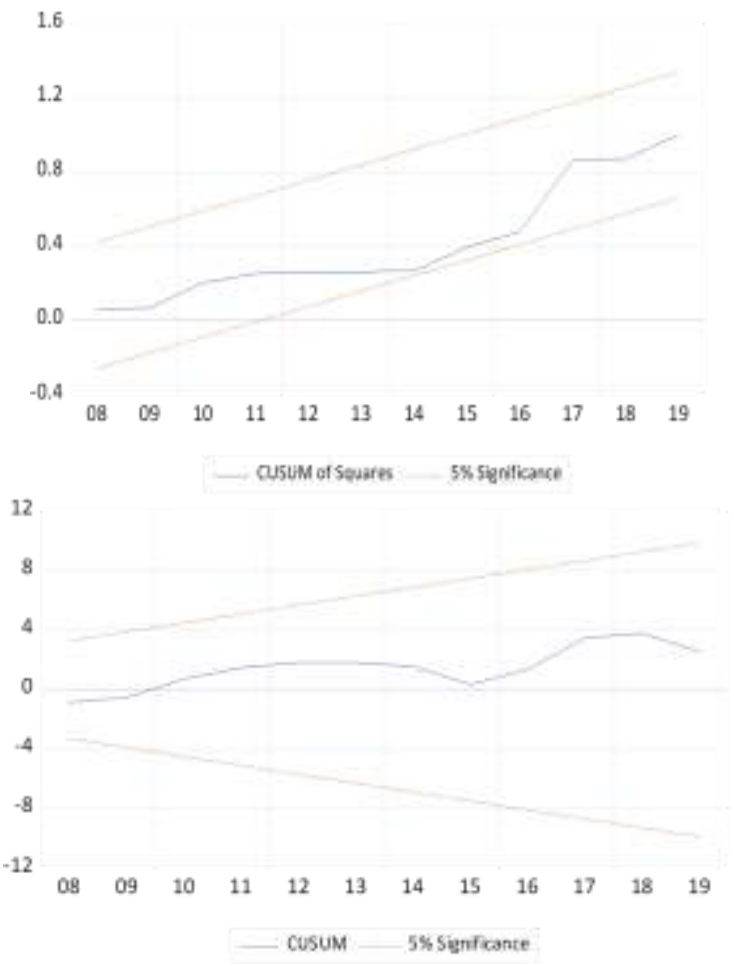

Figure 3: Stability Test for M2 


\subsection{Diagnostics Tests}

Several diagnostic test namely, serial correlation test, heteroscedasticity test and normality tests were performed. A detailed description of diagnostic tests is shown in Table 7. First, serial correlation tests were tested. Serial correlation determines how well the past values of a variable predict the future value of the same variable. Test results confirmed at 5 per cent significance level, it fails to reject the hypothesis that there is no serial correlation issue in variables.

Secondly, heteroscedasticity tests were performed. Since the $p$ value of Chi-Square is not less than 0.05 , it does not reject $\mathrm{H} 0$, which means that there is no heteroaskedasticity. According to the normality test of residuals, since $\mathrm{p}$-value is is greater than 0.05 , we do not reject $\mathrm{H} 0$ at 5 per cent level of significance and it can be concluded that residual are normally distributed.

Several significant findings have been discovered from this analysis. AS shown in Table 5, model 1and 2, real GDP and long term interest rate has strong significant relationship with money demand in the long run. As expected, the coefficient of real income (LRGDP) is positive and is highly significant.
Table 7: Diagnostic Test

\begin{tabular}{|l|l|l|l|}
\hline \multicolumn{1}{|c|}{ Model1 } & \multicolumn{3}{|c|}{ M1 } \\
\hline Test & $\begin{array}{l}\text { Test } \\
\text { Stat. }\end{array}$ & $\begin{array}{l}\text { Test } \\
\text { Result }\end{array}$ & Prob. \\
\hline Normality & $\begin{array}{l}\text { Jarque- } \\
\text { Bera }\end{array}$ & 4.268 & 0.118 \\
\hline $\begin{array}{l}\text { Serial } \\
\text { Correlations }\end{array}$ & $\begin{array}{l}\text { LM } \\
\text { Test }\end{array}$ & 2.217 & 0.329 \\
\hline $\begin{array}{l}\text { Heterosceda } \\
\text { sticity }\end{array}$ & $\begin{array}{l}\text { B.P } \\
\text { Godfrey }\end{array}$ & 23.673 & 0.209 \\
\hline Model2 & M2 & \\
\hline $\begin{array}{l}\text { Normality } \\
\text { (residual) }\end{array}$ & $\begin{array}{l}\text { Jarque- } \\
\text { Bera }\end{array}$ & 0.933 & 0.627 \\
\hline $\begin{array}{l}\text { Serial } \\
\text { Correlations }\end{array}$ & $\begin{array}{l}\text { LM } \\
\text { Test }\end{array}$ & 3.866 & 0.145 \\
\hline $\begin{array}{l}\text { Heterosceda } \\
\text { sticity }\end{array}$ & $\begin{array}{l}\text { B.P } \\
\text { Godfrey }\end{array}$ & 32.612 & 0.210 \\
\hline
\end{tabular}

Source: Authors Estimation

This finding is in line with the many studies done in the domestic and foreign countries and it confirmed the theoretical predictions (Nwude et al., (2018); Manamba, (2017): Anwar and Asghar 2012; Adikari 2015; Jegajeevan, (2015); Nandasiri et al., 2015; Khan, 1992). However, these findings are completely opposed to the previous findings established the notion that broad money is co-integrated with neither real income nor interest rate (Weliwita and Ekanayaka 1998; Dharmarathna, 1998). The positive income elasticity of 
money demand confirmed the importance of money under transaction and precautionary motives. This shows rapid monetization of the economy over the study period. Moreover, relatively large income elasticity of money demand is not uncommon in developing countries (Chowdhury, 1997). The more than unity elasticity of demand implies that increase in income leads to a higher increase in money demand which may create inflationary pressure in the economy. This situation can be endorsed by negative impact of inflation on money demand (Sulaiman and Hala 2011).

As shown in table 5, both 91 Treasury bill rate (LTBILL) and commercial banks average lending rate (LINTR) have long run impact on money demand. Interest rate has significant negative impact on money demand confirming the expected sign and previous literature (Nwude et al., (2018); Manamba, (2017); Anwar and Asghar 2012; Arize and Nam, 2012; Adikari 2015; Nandasiri et al., 2015). The 91 Treasury bill rates which is a short run interest rate have a negative and significant impact on broad money balance but not for narrow money balance. This finding is in line with the Dharmarathna (2009) in which long run interest rates were identified as a good predictor of explaining of money demand. Thus, this confirmed that commercial bank average lending rate as good proxy of the opportunity cost of holding money in Sri Lanka. Apart from the long run interest rates, short run interest rate (TBILL rate) is also important as TBILL rate has significant negative impact on broad money balance in the second model and confirmed by the Jegajeevan, (2015). This is due to the fact that savers and investors are highly worried on short run rates when they are making financial decisions under risk and uncertain environment. Similarly, INFR appeared as an important factor which determined M1 in the long run. INFR has negatively impact on both M1 and M2. This finding is in consonance with Nwude et al., (2018). For an instance, when INFR increases by $1 \%$ the demand for real narrow money balance decreases by $0.09 \%$ per annum. It means that when inflation goes up people are willing to substitute money for real assets than the financial assets. In the previous discussions, few studies suggested inflation rate in place of interest rate as a good proxy for money demand. Thus, apart from the interest rate inflation rate can be considered as opportunity cost variable.

Interest rate spread has a positive effect on money demand in the short run as well as in the long run for narrow money demand. It contradicts the findings of Abbas and Muhammad, (2003).

Government expenditure as a percentage of GDP has positive 
significant effect on money demand in the long run. According to the Keynesian theory expansionary fiscal policy actions may lead to increase the money demand (Vamvoukas, 1998; Umbreen et al.,2016).

Comparison of two models, clearly indicate that real exchange rate is not significant in explaining the money demand in the long run but in the short run the influence of exchange rate on money demand is significant and the sign of the coefficient was negative. This is confirmed by the studies done by Bahmani, (2011); Akinsi, (2003) and Bahmani-Oskooee and Malixi (1991). Depreciation of domestic currency in terms of foreign currency may lead to reduce the demand for holding local currency and high preference for holding foreign currency leads to reduce the demand for money. Referring to dummy variable introduced in the model shows that economic crisis has weak negative relationship in explaining money demand function in Sri Lanka. This means that financial crisis may have negative impact on money demand in Sri Lanka. The reason for the negative impact claimed that impact of financial crisis was mainly to the export sector in Sri Lanka. It affected to the trade account and hence exchange rate may depreciate. But, in the short run dynamics of the model indicated that financial crisis has significant positive impact on money demand confirming previous literature by Dharmadasa and Nakanishi (2013). Generally, real GDP, interest rate, inflation rate government expenditure and financial crisis can be identified as the major determinants of long run money demand in Sri Lanka.

\section{CONCLUSION}

This research was undertaken with a view to examining the stability of the money demand function in Sri Lanka over the period 1977-2019. The model frame work of the study was developed based on the deductive approach based on the empirical literature. The model developed on real money balance for M1 and M2 as dependent variable against the explanatory variables such as, real GDP, commercial bank average lending rate, 91 TBILL rates, inflation rate, real exchange rate, government expenditure, interest rate spread and economic crisis. These explanatory variables were conceptualized under scale variables; opportunity costs variables and other macroeconomic variables. The data analysis was based on the famous bound cointegration approach and Vector Error correction approach.

The results revealed that most of the variables are cointegrated and have long run relationship with money demand except short run TBill rates, real exchange rates and interest rate spread. The interest rates, inflation rates and 
economic crisis exert negative and significant effect on money demand in the long run. Further, real GDP and government expenditure exert positive significant effect on money demand in the long run. It is found that depending on the VECM model, variables such as real GDP, interest rate, real exchange rate, interest rate spread, government expenditure, and economic crisis were significant in explaining the money demand function in Sri Lanka. Thus, in the short run real GDP, financial crisis and interest rate spread exert positive significant effect on money demand in Sri Lanka whereas real exchange rates and interest rates exert negative impact on money demand.

Consistent with theoretical postulates, this paper finds that the demand for money positively responds to an increase in real GDP, interest rate spread and government expenditure to GDP and negatively to a rise in the interest, the rate of inflation and the economic crisis. The money demand function is found stable over time indicating both $\mathrm{M} 1$ and M2 are suitable for monetary policy formulation in Sri Lanka. These are the good predictors of the long run money demand. External stability factors namely real exchange rate may have a negative impact on money demand in the short run and but long run is insignificant. Further, economic crisis exert negative impact on broader money balances in the short run and also negative effect on money demand in the longer term as well. However, further empirical investigations are necessary in this regard. Thus, monetary authority should consider these effects of the external factors in formulating appropriate monetary policies. Finally, findings of the study provide the policy challenges that Sri Lankan economy meets to develop favorable macroeconomic environment in order to manage money demand for a sustainable growth.

\section{REFERENCES}

Abbas, V., and Muhammad, A., (2003). Demand for M2 in Developing Countries: An Empirical Panel Investigation, Discussion papers in Economics, Finance, and International Competitiveness, no 149, School of Economics and Finance, Queensland University of Technology

Adikari, A., (2015). An Empirical Study on Money Demand Function in Sri Lanka: 19932013, $6^{\text {th }}$ international Conference on Business \& Information ICBI - 2015, Faculty of Commerce and Management Studies, University of Kelaniya, Sri Lanka.

Akıns1, O., (2003). Modelling the demand for currency issued in Turkey, The Central Bank 
of the Republic of Turkey Research Department, Central Bank Review 1, 1-25

Arango, S., and Nadiri, MI., (1981), Demand for money in open economies. Journal of Monetary Economics, Volume 7, No. 1, 69-83. DOI:10.1016/03043932(81)90052-0

Arize, A. C., \& Nam, K. (2012). The Demand for Money in Asia: Some Further Evidence. International Journal of Economics and Finance, 4(8), 59-71. https://doi.org/10.5539/ijef. v4n8p59

Arize, A.C., \& Nam, K. (2012). The demand for money in Asia:Some further evidence. International Journal of Economics and Finance, 4(8), 59-71. DOI: 10.5539/ijef.v4n8p59

Azim, P., Ahmed, N., Ullah, S., \& Zakaria, M. (2010). Demand for money in Pakistan: an Ardle approach. Global Journal of Management and Business Research, 10(9), 6-10

Bahmani, S., (2011). Exchange rate volatility and demand for money in less developed countries, Journal of Economics and Finance vol. $37,442-452$

Bahmani-Oskooee, M. and Mohammad Pourheydarian (1990), Exchange rate sensitivity of demand for money and effectiveness of fiscal and monetary policies. Applied Economics, Vol. 22(7), 917-925. DOI: $10.1080 / 000368490000$ 00029

Barro, R. J. (1981) Output Effects of Government Purchases, Journal of Political Economy, 89, 1086- 1121

Barry, R., and Sumner, M., (2008). Demand for Money in Sri Lanka, 1952-2002, Applied Economics Letters 15(5), 343-347, DOI: 10.1080/1350485060070594 3

Bhatta, S. R. (2012). Stability of Money Demand Function in Nepal. Banking Journal of Nepal, 3(1)

Brown R.L., Gurbin J, Evans J.M., (1975). Techniques for Testing the Constancy of Regression Relations over Time. Journal of Royal Statistics of Social Sciences, 37, 149-163.

Central Bank Annual Report (2018), Central Bank of Sri Lanka,

Chowdhury, A.R., (1997). The Financial Structure and Demand for Money in Thailand, Applied Economics, 29(3), 401-409

Deravi, M. K., Hegji, C. E. and Moberly, H. D. (1990) Government Debt and the 
Demand for Money: An Extreme Bound Analysis, Economic Inquiry, 28, 390401

Dharmadasa, C. and Nakanishi, M., (2013), "Demand for Money in Sri Lanka: ARDL Approach to Cointegration", $\quad 3 r d$ International Conference on Humanities, Geography and Economics (ICHGE'2013) January 45, 2013 Bali (Indonesia) Proceeding Book, 143-147.

Dharmaratne, W., (2009). Demand for Money in Sri Lanka During the Post Liberalisation Period. Staff Studies, 34(1), 1-12, DOI: 10.4038/ss.v34i1.1237

Foresti, P., \& Napolitano, O., (2013). Modelling LongRun Money Demand: A Panel Data Analysis on nine Developed Economies, Applied Financial Economics, 23(22), 1707-1719.

DOI:10.1080/096031

07.2013.848024

Friedman M (1956). The Quantity Theory of Money: A Restatement, in M. Friedman, ed., Studies in the Quantity Theory of Money, Chicago, University of Chicago Press, 3-21

Hassan, S., Ali, U., \& Dawood, M. (2016). Measuring money demand function in Pakistan,(No.75496).Munic h Personal Re PEc Archive Measuring

Hayo, B. (1999) Estimating a European money demand function, Scottish Journal of Political Economy, 46, 22144

Hoffman DL, Rasche RH, Tieslau MA (1995). The Stability of Long-Run Money Demand in Five Industrial Countries, Journal of Monetary Economics, Vol. 35: 317-339

Hussaini, U., Muhammad, Yusuf, O., (2018). The Determinants of Money Demand Function in ASEAN-5 Countries, Global Journal of Management and Business Research: $B$ Economics and Commerce, Vol.18(1), Online ISSN: 2249-4588 \& Print ISSN: 0975-5853.

Jayatissa, R.A (1984), Monetary Analysis of Exchange Market Pressure in Sri Lanka (1972-1985), Staff Studies, Vol. 14 (2), 49-64, Central Bank of Sri Lanka

Jegajeevan, S. (2015). Validity of the Monetary Model of the Exchange Rate: Empirical Evidence from Sri Lanka. Staff Studies, 42(1), 47-74

Keynes, J.M. (1936). The General Theory of Employment, Interest and Money, New York: Harcourt, Brace and Co. 
Khan, I.M., (1992). The Demand for Money in Pakistan and India, Pakistan Economic and Social Review, Vol. 30(2), 181-190

Kontolemis, Z.G (2002). Money Demand in the Euro Area: Where Do We Stand (Today)? IMF Working Paper, No.02/185, 1-30

Manamba, E., (2017). An Econometric Analysis of Demand for Money and its Stability in Tanzania, Turkish Economic Review, Vol. 4(2)

Melih, O., (2014). Money Demad Function in Turkey: An ARDL Approach, The Journal of Socialand Economic Research, Vol 14, $1-27$

Nandasiri K., Sarath H.K., and Chandika, G., (2015). Theoretical Compliance of Money Demand Function of Sri Lanka, Sri Lanka Journal of Economic Research, Sri Lanka Forum of University Economists, 3(2)

Narayan, P.K., Narayan, S., \& Mishra, V. (2009). Estimating money demand function for South Asian Countries. Empirical Economics, 36(3), 685-696. DOI: $10.1007 / \mathrm{s} 00181-008-$ 0219-9

Nwude, E.C., Offor, K.O., and Udeh, S.N., (2018).
Determinats of Stability of Money Demand in Nigeria, International Journal of Economics and Financial Issuesd, Vol 8 (3), 340-353

Pesaran, M.H.,Y. Shin, and Smith, R.J (2001). Bound Testing Approaches to the Analyisi of Level Relationships, Journal of Applied Econometrics 16, 289-626

Rabindra, N., and Nirash, P., (2020). Stability of Money Demand Function in Saqrrc Region:A Panel Cointegartion Approach, Journal of economic Integration, Vol. 35(1)

Sarwar, H., Sarwar, M., \& Waqas, M. (2013). Stability of Money Demand Function in Pakistan. Economic and Business Review, 15(3), 197-212.

Simmons, R. (1992) An errorcorrection approach to demand for money in five African developing countries, Journal of Economic Studies, 19 (1), 29-48.

Sriram, S.S. (2000), A survey of recent empirical money demand studies; IMF Staff Papers, 47(3), 334-65.

Suliman, Z.S., and Hala, A.D. (2011). An Econometric Analysis of Money Demand Function in Sudan 1960- 
2010, Journal of Economics and International Finance, Vol. 3(16). DOI: 10.5897/JEIF11.122

Tan, E. C. (1997), Money demand amid financial sector developments in Malaysia. Applied Economics, Volume 29(9), 1201-1215.

DOI: $10.1080 / 000368497000$ 00011

Umbreen I., Dawood M., and Muhammad S.H., (2016). Revisiting Determinants of Money Demand Function in Pakistan, Journal of Economics Bibliography, 3(4)

Vamvoukas, G.A., (1998). The Relationship between Budget deficit and monay demand: Evidence from Small Economy, Applied Economics, 30(3), DOI: $10.1080 / 000368498325895$

Weliwita A, Ekanayake EM (1998). Demand for Money in Sri Lanka during the Post1977 Period: A Cointegration and Error Correction Analysis. Applied Economics, Vol.30, 1219-1229.

Weliwita, A. and E. M. Ekanayake (1998), Demand for money in Sri Lanka during the post-1977 period: A cointegration and error correction analysis. Applied Economics, Volume 30(9), 1219-1229
DOI:10.1080/000368498325 101

Wijewardena, W.A (1985), Interest Elasticity of Money Supply in Sri Lanka, Staff Studies, Vol. 15 No 1\& 2, pp 43-50, Central Bank of Sri Lanka. 
Rathnasiri R.A., Wayamba Journal of Management 12 (1)

\section{Appendix 1: Unit Root Test Results (PP Test)}

\begin{tabular}{|c|c|c|c|c|}
\hline Variable & Model & $\begin{array}{c}\text { Level } \\
\text { (t-stat) }\end{array}$ & $\begin{array}{c}\text { First Difference } \\
\text { (t-stat) }\end{array}$ & Decision \\
\hline \multirow[t]{2}{*}{ LM1 } & Intercept & -1.5891 & $-23.3635^{* * * *}$ & \multirow[t]{2}{*}{$\mathrm{I}(1)$} \\
\hline & Intercept and Trend & -3.2562 & $-23.4525 * * *$ & \\
\hline \multirow[t]{2}{*}{ LM2 } & Intercept & -0.0886 & $-4.9332 * * *$ & \multirow[t]{2}{*}{$\mathrm{I}(1)$} \\
\hline & Intercept and Trend & -1.8783 & $-4.9091 * * *$ & \\
\hline \multirow[t]{2}{*}{ LRGDP } & Intercept & -0.1066 & $-5.5295 * * *$ & \multirow[t]{2}{*}{$\mathrm{I}(1)$} \\
\hline & Intercept and Trend & -1.6803 & $-5.4685 * * *$ & \\
\hline \multirow[t]{2}{*}{ LTBILLS } & Intercept & $-3.2687 * *$ & $-8.7032 * * *$ & \multirow[t]{2}{*}{$\mathrm{I}(0)$} \\
\hline & Intercept and Trend & $-3.9299 * *$ & $-6.6196^{* * *}$ & \\
\hline \multirow[t]{2}{*}{ LINTR } & Intercept & $-3.7847 * *$ & $-9.6729 * * *$ & \multirow[t]{2}{*}{$\mathrm{I}(0)$} \\
\hline & Intercept and Trend & $-4.6864 * *$ & $-9.6929 * * *$ & \\
\hline \multirow[t]{2}{*}{ LINSP } & Intercept & $-4.4995 * *$ & $-14.8209 * * *$ & \multirow[t]{2}{*}{$\mathrm{I}(0)$} \\
\hline & Intercept and Trend & $-4.3923 * *$ & $-25.9784 * * *$ & \\
\hline \multirow[t]{2}{*}{ INFR } & Intercept & $-4.5996^{* *}$ & $-29.7578^{* *}$ & \multirow[t]{2}{*}{$\mathrm{I}(0)$} \\
\hline & Intercept and Trend & $--5.8731 * *$ & $-28.2890 * * *$ & \\
\hline \multirow[t]{2}{*}{ LER } & Intercept & $-4.5951 * * *$ & $-22.2173 * * * *$ & \multirow[t]{2}{*}{$\mathrm{I}(0)$} \\
\hline & Intercept and Trend & $-8.6152 * * *$ & $-25.9552 * * *$ & \\
\hline \multirow[t]{2}{*}{ LGEGDP } & Intercept & -1.2750 & $-24.1556 * * *$ & \multirow[t]{2}{*}{$\mathrm{I}(0)$} \\
\hline & Intercept and Trend & $-8.6502 * * *$ & $-23.2898 * * *$ & \\
\hline \multirow[t]{2}{*}{ FCR } & Intercept & $-2.9953 * *$ & $-5.7918 * * *$ & \multirow[t]{2}{*}{$\mathrm{I}(0)$} \\
\hline & Intercept and Trend & -2.9668 & $-5.6894 * *$ & \\
\hline
\end{tabular}

Note: $* * * * * *$ denotes significance at $10 \%, 5 \%$, and $1 \%$ level respectively

Source: Author Calculations 